\title{
ORIGIN OF LOW-CA, HIGH-CR GARNETS BY RECRYSTALLIZATION OF LOW-PRESSURE HARZBURGITES.
}

\author{
Bulatov, ${ }^{(1)}$ V.; Brey, ${ }^{(2)}$ G.P. and Foley, ${ }^{(3)}$ S.F . \\ (1) Institute of Lithosphere, Moscow, USSR.; (2) Max-Planck-Institut für Chemie, Saarstrasse 23, 6500 Mainz, \\ Germany; (3) Mineralogisch-Petrologisches Institut, Universität Göttingen, \\ Goldschmidtstrasse 1, 3400 Göttingen, Germany.
}

Garnets with exceptionally low CaO (0.5-4 wt\%) and high $\mathrm{Cr}_{2} \mathrm{O}_{3}$ ( $1-13$ wt\%) contents are commonly found as inclusions in diamonds as part of the peridotitic inclusion suite, but up to date there is no clear consensus as to their origin. Any hypothesis for their origin must account for both the low Cao and the high $\mathrm{Cr}_{2} \mathrm{O}_{3}$ contents, in a process which operated in, but may not have been restricted to, the earliest tectonic regimes applicable to the Earth's mantle.

Explanations of their formation have been principally of three types, of which the first two appeal to formation of the garnet in equilibrium with a melt phase, whereas the third explains the garnets as metamorphic products from garnet-free rocks:

(i) The garnets are part of a restitic garnet peridotite suite formed by the loss of a considerable "basaltic" melt fraction, probably komatiitic; the exceptionally low $\mathrm{Ca}$ contents are thus a measure of the extreme depletion of the restite.

(ii) The low Ca-garnets crystallized from a melt which was itself derived as a "second-stage" melt from an extremely depleted peridotite type such as harzburgite. Such a melt would be enriched in $\mathrm{MgO}$ and poor in $\mathrm{Ca}, \mathrm{Al}$ and $\mathrm{Na}$ amongst the major elements.

(iii) The garnets are metamorphic products formed from reequilibration of subducted oceanic crustal material, either serpentinite or harzburgite.

Here we summarize experimental results of three types which have bearing on the above hypotheses: (i) Partial melting experiments on an anhydrous pyrolite composition with analyses of restitic garnets, (ii) sandwich experiments on the equilibrium between basaltic melt and spinel peridotite, which catalogue the composition of spinels in equilibrium with basaltic melt over a range of pressure and temperature, and (iii) near-solidus experiments on an olivine lamproite composition, which documents the composition of garnets crystallized in a very CaO-poor melt at high pressures. These studies lead us to the conclusion that low-CaO, high-Cr2O3 garnets most probably originate by metamorphic reequilibration of $\mathrm{Cr}$-spinel harzburgite, and that the $\mathrm{Cr}-$ spinel originally formed at pressures below $10 \mathrm{Kbar}$.

I. MORB-Pyrolite melting experiments

Experiments on dry melting were carried out at 50 and 60 $\mathrm{kb}$ on MORB-Pyrolite (Green et al., 1986) and experiments below the solidus on a similar primitive mantle composition (Brey et al., 1990). The $\mathrm{Cr}$ contents of garnets produced in these experiments are low and constant (even $200^{\circ} \mathrm{C}$ above the 
solidus) over a range of temperatures from $900-1800{ }^{\circ} \mathrm{C}$, whereas CaO decreases from 6 wt\% to 3.5 wt\% (Fig. 1). The experimentally produced garnets do not overlap in composition with natural Cr-rich subcalcic garnets. These garnets therefore do not originate from residues of partial melting at high pressures.

II. Spinel-peridotite/basalt sandwich experiments

Sandwich-type experiments on partial melting of a

primitive mantle composition were carried out from 5 to 20

$\mathrm{kb}$. Mineral separates from a primitive spinel lherzolite were recombined such that the centre of the sandwich consisted of spinel and clinopyroxene (the low-melting components)

surrounded by olivine, orthopyroxene and spinel and

clinopyroxene less the amount placed in the centre. The bulk corresponded to the original compositon. Large melt pools are created at temperatures above the solidus and melt

composition and restite mineral phases can be measured very easily with the electron microprobe. Restite spinels become enriched in $\mathrm{Cr}$ with increasing temperature and depleted in $\mathrm{Al}$ (Fig. 2). Spinels with the highest $\mathrm{Cr} / \mathrm{Al}$ ratios are produced at lowest pressures and highest temperatures. Such Cr-rich spinel harzburgites will transform at high pressures to garnet harzburgites with garnets having low $\mathrm{Ca}$ and high $\mathrm{Cr}$. Subduction or another type of removal to high pressure may be the process to bring the spinel harzburgites to great depth.

III. Olivine lamproite melting experiments

Experiments on lamproites may serve to model a very depleted mantle source in terms of major elements. No garnet is found near the liquidus up to pressures of $55 \mathrm{~kb}$ (Foley, 1989 and unpublished results), but experiments close to the solidus yield ol, phlog, opx and garnet. These garnets are always rich in $\mathrm{CaO}(5.8-7.4 \mathrm{wt} \%)$ and poor in $\mathrm{Cr}_{2} \mathrm{O}_{3}(<1 \%)$ and are not counterparts of the Cr-rich subcalcic garnets found in kimberlites.

From the presentation of experimental data above it appears that the only reasonable process to generate Cr-rich subcalcic garnets is that of metamorphic recrystallization of a Cr-spinel harzburgite. We envision harzburgite because the Ca-poor nature of the garnets does not allow cpx to be present and we favour Cr-spinel because the high $\mathrm{Cr}$ in garnet must come from there. Cr-spinel harzburgites are the residues of high degrees of partial melting at low pressures of plagioclase or spinel peridotite. These protoliths were subsequently transferred to high pressures.

Brey, G.P., Köhler, T. and Nickel, K.G. (1990), J.Petrol. 31, $1313-1352$

Foley, S.F. (1989), In: Jaques, A.L., Ferguson, J. and Green, D.H., "Kimberlites and Related Rocks." Blackwells,

Melbourne, 616-631

Green, D.H., Falloon, T.J., Brey, G.P. and Nickel, K.G. (1986), Fourth International Kimberlite Conference. Extended Abstracts, 181-183 


\section{COMPOSITION OF GARNETS}

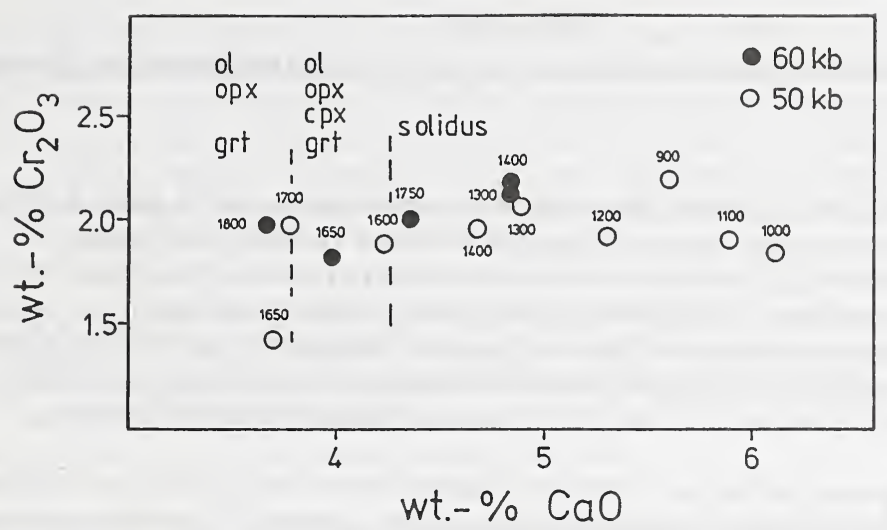

Fig. 1: Ca-Cr relationship of experimentally produced garnets in a pyrolite composition. Small numbers are temperatures in ${ }^{\circ} \mathrm{C}$.

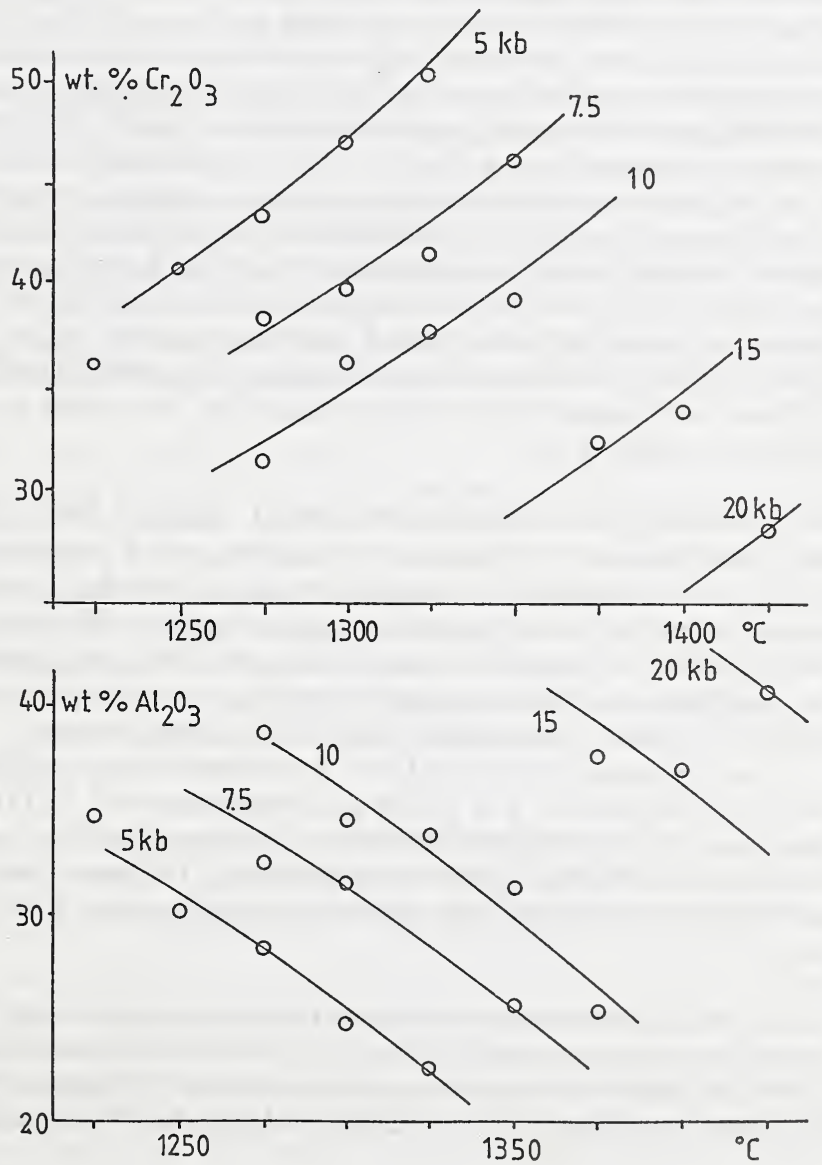

Fig. 2: Composition of spinel from partial melting experiments on a natural primitive upper mantle composition 